\title{
A REVIEW ON PERFORMANCE OF PERVIOUS CONCRETE USING WASTE MATERIALS
}

\author{
Sukamal Kanta Ghosh ${ }^{1}$, Ananya Chaudhury ${ }^{2}$, Rohan Datta ${ }^{3}$, D.K.Bera ${ }^{4}$ \\ ${ }^{1,2,3}$ M. Tech Student, School of Civil Engineering. KIIT University, Bhubaneswar, Odisha, India \\ sukamalghsh@gmail.com,ananya.chaudhury@ymail.com,rohan.datta1992@gmail.com \\ ${ }^{4}$ Assistant Professor, School of Civil Engineering. KIIT University, Bhubaneswar, Odisha, India \\ dberafce@kiit.ac.in
}

\begin{abstract}
Pervious concrete is one of the most promising sustainable material nowadays. Pervious concrete is the mixture of cement, smaller size coarse aggregate, water and admixture. As cement industry is one of the most polluted industry, so for reducing the pollution and cost of concrete cement may be fully or partially replaced by waste materials like fly ash, rice husk ash, waste rubber tire, furnace slag, silica fume, solid waste etc. This paper illustrates the performance of pervious concrete with these sustainable materials replacing or partially replacing cement \& aggregate. It is observed from the study that compressive strength of pervious concrete is increasing by introducing fly ash, furnace slag, and rice husk ash, silica fume, and solid waste (glass powder, ceramic waste, bottom ash). Whereas compressive strength is decreasing by addition of rubberized materials. Permeability is increasing with furnace slag, ceramic waste but glass powder, silica fume has no effect on permeability. Though rubberized materials decreases the tensile strength and compressive strength of pervious concrete, it increases the abrasion resistance \& freezing-thawing resistance. Partial addition of rice husk ash, furnace slag, silica fume, glass powder also enhance tensile strength of pervious concrete. All the above mentioned materials are environment friendly but solid waste, furnace slag and silica fume has the highest contribution to the strength and permeability of pervious concrete.
\end{abstract}

Keywords: Pervious concrete, fly ash, rice husk ash, rubber tire, furnace slag, silica fume, solid waste.

\subsection{INTRODUCTION}

Over the last few decades increasing awareness of human being about environmental protection and preservation guides some new techniques. Pervious concrete is one these modern technologies. Pervious concrete is an innovative approach to control, manage and treat the storm water runoff. Sometimes it also known as 'no-fine', 'permeable', 'porous' or 'gap-graded' concrete. The rapid population over the world leads rapid urbanization and as a result the earth surface is being covered with impervious surface

like buildings and pavements. Since these kind of surface does not permit storm water to percolate underground through it, the runoff is increasing these days and causing urban floods. It also affects underground water level.Pervious concrete is the special type of concrete which contains interconnected voids and these voids or pores allows storm (and rain) water to percolate underground.Thus pervious concrete is the best way to solve or minimize those problems [1].

Pervious concrete mostly used as a paving material but it also may use for various purpose other than pavement like parking areas, tennis court, fish hatcheries, zoos, noise barriers, slope stabilization etc.

Pervious concrete is a mixture of cement, water, coarse aggregate, admixture and/or supplementary materials. As cement industry is one of the most populated industry and it consumes lots of non-renewable energy it is very essential to partial or full replacement of cement to protect our environment. Now a days disposal of many so waste materials like fly ash, RHA, silica fume, waste tires, furnace slags etc. are the huge headache for most of the developing countries. So cement and coarse aggregates can replace or partially replaced by these wastes which guides sustainable development. If we replace Cement and coarse aggregates by some other materials it may also be good from economic consideration. Over the last few years lots of research have been done by scientists conserve the cement and coarse aggregates and to minimize the disposal problems of waste materials by using these wastes as ingredients of pervious concrete[5].

\subsection{LITERATURE STUDY}

\subsection{Fly ash}

Fly ash is a by-product of the combustion of crushed coal in thermal power plant. It is widely used as supplementary cementitious material in concrete mixture. A portion of Portland cement in pervious concrete can be replaced by fly ash. Not only fly ash gives a better final product but also it is a sensible way to control the pollution. The overall performance of pervious concrete can be enhanced by using fly ash as a mineral admixture. $\mathrm{CO}_{2}$ emissions created during cement production are greatly reduced by using fly ash as a partial replacement of cement, which decreases the 
negative effect on our atmosphere. Fly ash powder and cross-section of fly ash particles are shown in Fig. 1(a) and 1(b) respectively.

Fly ash is fine,powdery particle with spherical shape.It is either solid or hollow and amorphous(glassy)in nature like silt. Its chemical properties depend upon the type of ignited coal and the techniques used for handling or storage. Table 1 shows the chemical properties of fly ash.

Yukari et al.(2009)experimented on the properties of pervious concrete by replacing the cement with $20 \%$ and $50 \%$ of fly ash.He concluded that compressive strength decreases with increment of fly ash content. When fly ash content is increased up to $20 \%$ in concrete permeability is decreasing,but after that when fly ash content reach to $50 \%$ in concrete permeability is increased which is nearly similar to no fly ash pervious concrete [2].

Ravindrarajah et al.(2010)investigated the properties of pervious concrete by replacing $20 \%$ and $50 \%$ of cement with fly ash.He found out that pervious concrete with high porosity shows low compressive strength and high permeability.The results of their investigation described that the permeability of pervious concrete was not notably affected when $50 \%$ of cement was replaced by fly ash and compressive strength will decrease with increase of the fly ash content [3].

$\mathrm{Na}$ Jin(2010)worked on "fly ash applicability in pervious concrete" using $2 \%$ and $32 \%$ fly ash in pervious concrete.He found out that using $2 \%$ fly ash pervious concrete can achieve higher compressive strength than that of using $32 \%$ fly ash in pervious concrete.He also indicated that fly ash helps to increase long term compressive strength of pervious concrete [4].

\subsection{Rice husk ash (RHA)}

Rice Husk Ash (RHA) is an agricultural waste material. As there are many difficulties involves in its disposal RHA is becoming an environmental hazard for each and every rice producing countries. RHA is produced in large quantities every year all over world. India alone produce 6 million tons of Rice Husk Ash per year [6].Rice husk and RHA are shown in Fig. 2(a) and 2(b) respectively.

S. Talsania et al. (2015) investigate the effects of pervious concrete by partial replacement of cement with $10 \%$ and $30 \%$ of Rice husk ash. He concluded that compressive strength and flexural strength of pervious concrete increase up to $10 \%$ replace of cement with RHA. Beyond that compressive and flexural strength are starting to decrease [6].

Akeke et al. (2013) investigated the properties of concrete by replacing cement with $10 \%, 20 \%$ and $25 \%$ RHA. According to him flexural strength and split tensile strength are decreasing gradually with increase of RHA content from 10 to $25 \%$. Whereas there was not any significant effect on compressive strength with the increment in RHA content [7].

Obilade (2014) stated that when cement is partially replaced by RHA,the optimum addition of RHA content should be in the range of 0 to $20 \%$. Compressive strength of concrete is reduces with the increment of RHA content [8].

Saied Heasami et al. (2014) investigates the effect of RHA and fibre on mechanical properties of pervious concrete. He concluded that the optimum percentage of RHA without fibres is $8 \%$ while it is between 8 to $10 \%$ with fibres, he added the permeability of pervious concrete by adding $12 \%$ RHA content is significantly higher than adding $10 \%$ of RHA content. But addition of $10 \%$ RHA content gives higher compressive, tensile and flexural strength than $12 \%$ RHA content[10].

Kartini et al. (2006) who investigated the properties of concrete by using RHA (20\% and $30 \%$ ) as a replacement of cement concluded that RHA does not improves flexural and tensile strength. Whereas up to $20 \%$ it does not having any major effect on compressive strength [9].

\subsection{Furnace slag}

Slag is the supplementary waste materialacquired during steel and iron making processes [11].Relying on the iron and steel making process different types of slag can be found.Blast Furnace Slag (BFS) is produced in the time of liquefaction and depletion of iron ore in a blast furnace. See Fig. 3(a).Electric Arc Furnace Slag (EAFS) is made in the course of transformation of hot metal to crude steel or during the melting of refuse in an electric arc furnace. See Fig.3(b).Air cooled and ground granulated blast furnace slag(GGBFS) are used as aggregates in place of natural aggregates in pervious concrete [12,13].Despite having no pozzolanic property, electric arc furnace slag is being widely used as aggregate in pervious concrete [14].

Table 2 compares the physical and mechanical properties of natural aggregates, blast furnace slag and electric arc furnace slag. Chemical composition of blast furnace slag and electric arc furnace slag are given in Table 3.

R.Alizadeh et al. (2003) carried out experiments on slag aggregate concrete and natural aggregate concrete. The result showed that concretes using slag as aggregate achieve greater value of compressive strength, flexural strength, tensile strength and modulus of elasticity compared to concretes using natural aggregate [15].

M.A.Khafaga et al. (2014) investigated the properties of electric arc furnace slag as aggregate. According to experimental values, using $66.67 \%$ of electric arc furnace slag as a replacement of naturalcoarse aggregate gives maximum utility of compressive strength, flexural strength, tensile strength and modulus of elasticity. It also increases water permeability which is suitable for pervious concrete [16]. 
Rasiah et al. (2012) studied the properties of pervious concrete by replacing $35 \%$ and $70 \%$ of cement with ground granulated blast furnace slag(GGBFS).From the experiments they stated that GGBFS in pervious concrete can increase the compressive strength but it can decrease the permeability [17].

W.Yeih et al. (2015) investigated on an alternative of gravels to produce pervious concrete which is electric arc furnace slag. It is found out that the pervious concrete produced by using electric arc furnace slag has a higher water permeability and higher compressive strength than that produced with gravels [18].

\subsection{Silica fume}

Silica fume is an amorphous polymorphic substance composed of $\mathrm{SiO}_{2}$ i.e.silica. Silica fumeis an ultrafine powder formed as a by-product of the production of silicon and ferrosilicon alloy and contains spherical shaped particles with an average diameter of $150 \mathrm{~nm}$. Fig. 4 (a), 4 (b) and 4 (c) show different sizes of silica fume. It is also known as micro silica.

Silica fume is composed of spherical particles with diameter less than $1 \mu \mathrm{m}$, with an average of about $0.15 \mu \mathrm{m}$. Thus, the average cement particleis approximately 100 times larger than silica fume. Its bulk density depends on the extent of densification in the silo and ranges from 130 (un-densified) to $600 \mathrm{~kg} / \mathrm{m}^{3}$. The specific gravity of silica fume usually varies from 2.2 to 2.3 . The specific surface area of silica fume varies from 15,000 to $30,000 \mathrm{~m}^{2} / \mathrm{kg}$. Chemical and physical characteristics of silica fume is shown on Table 4.

Alsana Bashir (2014), concluded that the optimum silica fume content for getting least permeable concrete without extensively affecting the compressive strength of the concrete is 15 percent by weight of cementas partial replacement. At this content of silica fume use of superplasticiser is necessary to get the desired workability[19].

Ha-Won Song (2009), stated that the permeability of concrete reduces when the silica fume content is about 8 percent and it keeps on reducing from 8 to 12 percent silica fume content. But, if the silica fume content is more than 12 percent the permeability is marginal or in few cases increases for increased water to binder ratio [20].

Jing Yang (2002), also found out that the strength of pervious concrete enhances greatly with the addition of silica fume [21].

M.I.Khan (2001), concluded that the optimum permeability and strength values of concrete are yielded due to the influence of 8 to12 percentof silica fume [22].

\subsection{Waste rubber tire}

Waste rubber tires are another environmental hazard produced by automobile industries. As the waste rubber tires are not biodegradable and disintegrate in nature, the cheapest way to decompose it is by burning them which discharge a huge amount of smoke. So reapplication of waste rubber tires are necessary now a days. Due to its elasticity, lightweight, energy absorption, heat insulating property it is becoming a promising material in construction industry $[24,25]$.

The rubber tires can be used with three difference particle sizes namely very fine, fine and coarse. These are fine crumb rubber, crumb rubber, tire chips. These can be used as replacement of cement and coarse aggregate also. The concrete made by rubber tires known as rubberized concreteWaste rubber tires, tire chips and crumb rubberare shown in Fig. 5(a),5(b) and 5(c) respectively.

Mehmet et al (2014) experimented on the properties of pervious concrete containing waste tires and calculated using tire chips and crumb rubber the compressive strength of porous concrete is $6.45 \mathrm{MPa}$ where the compressive strength of Pervious concrete ranges from 3 to $30 \mathrm{MPa}$. The permeability of Pervious concrete fell into 0.25 to $0.61 \mathrm{~cm} / \mathrm{s}$ which are recommended limit of Pervious concrete. The fracture energy is increased with using tire chips and crumb rubber whereas fracture energy is decreasing by using Fine crumb rubber [24].

Warndkar A.A et al (2015) investigated the properties of concrete by applying waste rubber as coarse aggregate and concluded that compressive strength of rubberized concrete is less in comparison to conventional concrete but it is within acceptable limit. The flexural strength is also reduced in comparison to normal concrete but the cost of rubberish concrete is much less than conventional concrete [26].

EI-Gammal, A et al (2010) concluded in his paper that there was a significant reduction in compressive strength and density when tire chips used as full replacement of coarse aggregate. He recommend this type of concrete should be used in curbs, roads etc. [25].

Mehmet et al (2014) investigated the abrasion and freezing thawing resistance of pervious concrete and concluded that the utilization of rubbers remarkably improves the abrasion resistance and freeze thaw resistance of pervious concrete. Thus freezing thawing durability of pervious concrete can be solved easily [27].

\subsection{Solid waste}

The permeabilityand strength of pervious concrete can be increased and the cost of pervious concrete can be decreased by replacing cement with various industrial waste materials such as waste glass powder, hypo sludge, ceramic waste and municipal solid waste incinerator (MSWI) bottom ash.

\subsubsection{Waste glass powder}

Glass is a non-crystalline substance with high silica content, thus it is potentially pozzolanic when particle size is less than $75 \mu \mathrm{m}$. Out of concern for the environmental effects 
associated with cement manufacturing,efforts have been made in concrete production industry to use waste glass powder as partial replacement of coarse aggregates or fine aggregates and cement. It has been found that up to particle size of $75 \mu \mathrm{m}$ or less, glass powder serves as an effective cement supplementary material which can prevent reaction of alkali and silica. See Fig. 6(a) and 6(b).Chemical properties of glass are given in Table 5.

Bhupendra Singh Shekhawat(2014), concluded that the compressive, tensile and flexural strength increases effectively for glass powder concrete, when compared with conventional concrete. It also increases the durability and workability of the concrete [28].

Dr.G.Vijayakumar (2013), found out that replacement of cement by 20 percent, 30 percent and 40 percent glass powder increases the compressive strength by 19.60 percent, 25.30 percent and 33.70 percent respectively whereas replacement of cement by 40 percent glass powder increases the split- tensile strength by 4.40 percent respectively and replacement of cement by 20 percent , 30 percent and 40 percent glass powder increases the flexural strength by 83.07 percent, 99.07 percent and 100 percent respectively [29].

Dhanaraj MohanPatil(2013), found out that addition of glass powder increases the strength of concrete and the replacement of cement by 20 percent glass powder achieves maximum strength as compared to that of normal concrete [30].

\subsubsection{Hypo sludge}

Hypo sludge is the waste product produced in paper manufacturing industry. Because of the presence of silica and magnesium hypo sludge behaves like cement. The setting of the concrete improves due to this silica and magnesium. See Fig. 7(a) and 7(b). Table 6 shows the chemical properties of hypo sludge.

Abhinandan Singh Gill (2014), found out that the use of hypo sludge at optimal conditions of calcinations exhibits high pozzolanic property and permits its possible reuse as a pozzolanic material. This article also found out that the hypo sludge concrete shows higher water absorption than traditional concrete and the cost analysis indicates that with addition of hypo sludge the cost of concrete decreases [31].

JayeshkumarPitroda (2013), concluded that use of hypo sludge reduces the compressive strength of cement but at the same time stated that incorporation of hypo sludge in concrete can help the paper industry to save the disposal costs and can produce a 'greener' concrete. His research concluded that hypo sludge can be an innovative cement replacement construction material [32].

\subsubsection{Ceramic waste}

Minerals present in clay become highly reactive upon incineration at temperatures between $600-900^{\circ} \mathrm{C}$, after which they are ground to cement fineness. They are mainly formed by siliceous and aluminous compounds. Thermal treatments causes loss of water which leads to the disruption of their crystalline structure, which consequently results in their conversion into unstable amorphous state. If at that state they are mixed with calcium hydroxide $(\mathrm{CaOH})$ and water, they undergo pozzolanic reaction and consequently form compounds with better strength and durability. Therefore, they can be potentially used in mortar and concrete. See Fig. 8(a) and 8(b). Chemical characteristics of ceramic waste is given in Table 7.

O. Zimbili (2014), discussed that ceramic wastes are suitable to be used in the construction industry, as they were found to be performing better in properties such ascompressive strength, permeability,densityand durability,than normal concrete [33].

Amitkumar D. Raval (2013), concluded that there is an increment in the Compressive Strength of M20 grade concrete in case of replacementof cement with ceramic powder up to 30 percent by weight of cement and further replacement will decrease the Compressive Strength of the concrete. He found out that 30 percent cement replacement with ceramic powder, yielded a compressive strength of $22.98 \mathrm{~N} / \mathrm{mm} 2$ and as well as there was a reduction in cement cost by 12.67 percent in case of M20 grade and hence it can be concluded that it is more economical to use ceramic waste powder without compromising standard concrete strength. Thus, it becomes economicallyand technically viable and feasible [34].

Eva Vejmelková (2012), presented that ceramic wastewhen ground to a suitable fineness can be treated as an efficient pozzolanic material which is suitable for the replacement of a portion of Portland cement in concrete production industry. This solution may have enough significance fromeconomic and environmental aspects. $\mathrm{He}$ also mentioned that ceramic waste used as recycled material in the production of concrete presents no severe $\mathrm{CO} 2$ burden to the environment. Its price is much lower than Portland cement [35].

\subsubsection{Municipal solid waste incinerator bottom ash (MSWIBA)}

The bottom ash is the remnant of controlled combustion of domestic and municipal solid waste of modern waste to energy plant. In principle bottom ash can be used as aggregate in the production of normal strength concrete because of its chemical and mineralogical characteristics. Different sizes of MSWIBA are shown in Fig. 9(a), 9(b) and 9(c).Table 8 shows the chemical properties of bottom ash.

Wen-Ten Kuo (2013), found out that freshly mixed pervious concrete prepared using 12.5-mm washed MSWIBA has unit weight of approximately $1653-2080 \mathrm{~kg} / \mathrm{m} 3$ and it further increases with increasing filling paste ratio. He also mentioned that no significant differences has been found in, permeability coefficients, compressive strengths or 
connected porosities between pervious concrete made by using washed MSWIBA and pervious concrete made by using natural aggregate but, pervious concrete prepared by using9.5-mm washed MSWIBA had less connected porosity, permeability coefficient and bending strength than pervious concrete preparedby using $12.5-\mathrm{mm}$ washed MSWIBA [36].

Hashim Mohammed Alhassan (2012), stated that MSWIBA is a light weight material than natural gravel and sand which is helpful in fills construction on grounds having low bearing capacity. MSWIBA is a porous material quite comparable to sand due to which it enhances free draining which can prevent build-up of pore water pressure in embankments and fills. He also mentioned that MSWIBA is a compactable and well graded material which can be used as a hard road sub base material according to the C.B.R result values. Besides this it can be concluded that it is a fairly durable and stable material like natural sand based on the shear strength parameters. From this study, Municipal solid waste incineration achieved 93 percent volume reduction and 62 percent weight reduction. This study concluded that the municipal solid waste incinerator bottom ash has the potential to behave as civil engineering construction material [37].

\subsection{CONCLUSION}

From the study the following points to be derived:

$>$ Utilization of fly ash in pervious concrete by replacing a portion of cement gives better long term compressive strength and it will decrease with increase in fly ash content while it is not effecting Permeability.

$>$ In pervious concrete RHA can't be use as full replacement of cement. We should use it as partial replacement of cement and the RHA content should not be more than $10-12 \%$. More than that will reduce the compressive strength, flexural strength and permeability also which are the major properties of pervious concrete.

$>$ Ground granulated blast furnace slag (GGBFS) can be used in place of cement but it is not ideal for pervious concrete as it decreases permeability. But in case of electric arc furnace slag not only it gives higher water permeability and compressive strength than gravels but also provides greater anti-skid capability and better interface bonding due to interlocking effect.

$>$ Though the permeability of the pervious concrete decreases to some extent with the addition of silica fume, the strength of the concrete increases to a great extent. So, we can say that the influence of silica fume on strength of the concrete is much more than its influence on permeability of the concrete. If more amount of silica fume is added then it is advised to add superplasticiser to improve workability.

$>$ The mechanical properties of pervious concrete experiences a negative effect whenwaste rubber tires are introduced as its ingredients i.e. the utilization of rubber materials in pervious concrete reduces its compressive strength and flexural strength. Though compressive strength decreases but it is within the acceptable range. On the other hand the abrasion resistance and freeze thaw improves significantly, whereas Permeability is also fell into acceptable limits by using waste rubber tires. These are the most important parameters reqd. for a pervious concrete pavement. So rubberish pervious concrete can be used on low volume traffic roads, curbs, shoulders etc.

$>$ The compressive, tensile and flexuralstrength characteristics ofporous concrete will significantly increase with the addition of glass powder as well as it will help in improving the durability and workability of the concrete.

$>$ Addition of hypo sludge will improve the permeability of the pervious concrete as well as it can be used as pozzolanic material due to its high pozzolanic property. Although use of hypo sludge will reduce the compressive strength but it will help in producing "greener" concrete which is a very environment friendly way of concrete production.

$>$ Ceramic powder upon addition will improve the permeability and durability of concrete. Besides these properties it also helps in increasing the compressive strength of concrete and at the same time acts as good pozzolanic material. Since ceramic powder is obtained from ceramic wastes so the addition of ceramic powder to improve the properties of concrete is a very economical process.

$>$ MSWIBA is a very stable and durable material, so, upon addition it will increase the durability of concrete but it does not have much influence on the permeability and strength of the pervious concrete.

$>$ It is crystal clear that the utilization of these waste material is beneficial from the environmental and economical point of view.

\section{REFERENCES}

1.Shihui Shen, Maria Burton, Bertram Jobson, Liv Haselbach, "Pervious Concrete With Titanium Dioxide As A Photocatalyst Compound For A Greener Urban Road Environment",Construction and Building Materials 2012;35: 874-883.

2.Yukari Aoki., M.E.Thesis "Development of Pervious Concrete",Faculty of Engineering and Information Technology,University of Technology,Sydney,June 2009.

3.Sri Ravindrarajah,A.Yukari, "Environmentally Friendly Pervious Concrete for Sustainable Construction", $35^{\text {th }}$ Conference on Our World in Concrete \& Structures,Singapore,25-27 August,2010.

4.Na Jin,M.S.Thesis "Fly Ash Applicability in Pervious Concrete", The Ohio State University,2010.

5.Siddharth talsania, jayeshkumar pitroda, prof. Chetna m. Vyas, "A Review of Pervious Concrete by Using Various Industrial Waste Materials",2015; 2(12) pp 142-151.

6.Siddharth Talsania, Jayeshkumar Pitroda, Chetna M. Vyas., Effect of rice husk ash on properties of pervious concrete, Int. J. Adv. Engg. Res. 2015; 296-299.

7.Godwin A. Akeke, Maurice E. Ephraim, Akobo, I.Z.S and Joseph O. Ukpata, "Structural Properties OfRice Husk 
Ash Concrete", International Journal of Engineering and Applied Sciences, Volume 3, No 3, May 2013.

8.Obilade, "Use Of Rice Husk Ash As Partial Replacement For Cement In Concrete", InternationalJournal of Engineering and Applied Sciences, Volume 5, No 4, Sept 2014.

9.Kartini,Mahmud, Hamidah, "Strength Properties Of Grade 30 Rice Husk Ash Concrete", $31^{\text {st }}$ Conference on Our World In Concrete \& Structures: 16 - 17 August 2006, Singapore.

10.Saeid Hesami, Saeed Ahmadi, Mahdi Nematzadeh, Effects of rice husk ash and fibre on mechanical properties of pervious concrete pavement,Construction and Building Materials 53 (2014) 680-691.

11.Geiseler,J., "Slag-Approved Material For Better Future",Proceeding of International Symposium on the Utilization of Metallurgical Slag(ISUS 99),Beijing,China, 1999.

12.Parlenko,S.I., "Fine Grained Cement less Concrete Containing Slag from Foundry",Proceeding of the $6^{\text {th }}$ International Conference on Fly Ash,Silica Fume,Slag and Natural Pozzolanas in Concrete,Bangkok, Thailand,1998.

13.Kamal,M.,Gailan,A.H.,Haatan,A.,Hameed,H., "Aggregate Made from Industrial Unprocessed Slag",Proceeding of the $6^{\text {th }}$ International Conference on Concrete Technology for Developing Countries, Amman,Jordan,2002.

14.CMI,Use of Steel Slag in Civil Engineering Issues,Technical Report, No.-3, Construction Material Institute,Faculty of Engineering,University of Tehran,2001.

15.Alizadeh,R.,Chini,M.,Ghods,P.,Hoseini,M.,Montazer,Sh. ,Shekarchi,M., "Utilization of Electric Arc Furnace Slag as Aggregate in Concrete-Environmental Issues", $6^{\text {th }}$ CANMET/ACI International Conference on Recent Advances in Concrete Technology,Bucharest,Romania,pp.451-464,June 2003.

16.Khafaga,A.M.,Fahmy,S.W.,Sherif,A.M.,Hamid,A.S.N.A. , "Properties of High Strength Concrete Containing Electric Arc Furnace Steel Slag Aggregate",Journal of Engineering Sciences,Assiut University,Vol.-42,No.3,May 2014.

17.Rasiah Sriravindrarajah,Neo Derek Huai Wang,Lai Jian Wen Ervin, "Mix Design for Pervious Recycled Aggregate Concrete",International Journal of Concrete Structures and Materials,Vol.-6,No.-4,December 2012.

18.Weichung,Y.,Tun,C.F.,Chang,J.J.,Huang,R., "Properties of Pervious Concrete Made with Air Cooling Arc Furnace Slag as Aggregates",Construction and Building Materials 93,2015.

19.Alsana Bashir, 2014 "Study of Permeability and Compressive Strength of Silica Fume Concrete" International Journal of Engineering and Advanced Technology (IJEAT), Volume-3, Issue-4.

20.Ha-Won Song, 2009 "Estimation of the permeability of silica fume cement concrete" Construction and Building Materials 24 (2010) 315-321.
21.Jing Yang, 2002 "Experimental study on properties of pervious concrete pavement materials" Cement and Concrete Research 33 (2003) 381-386.

22.M.I. Khan, 2001 "Strength, permeability, and carbonation of high-performance concrete" Cement and Concrete Research 32 (2002) 123-131.

23.Vagelis G, 1999 "Experimental investigation and theoretical modelling of silica fume activity in concrete" Cement and Concrete Research 29 (1999) 79-86.

24.Mehmet Gesoglu, Erhan Guneyisi, Ganjeena Khoshnaw, Suleyman Ipek. Investigating properties of pervious concretes containing waste tire rubbers, Construction and Building Materials 63 (2014) 206-213.

25.El-Gammal, A.; A. K. Abdel-Gawad; Y. El-Sherbini, and A. Shalab., Compressive Strength of Concrete Utilizing Waste Tire Rubber, Journal of Emerging Trends in Engineering and Applied Sciences (JETEAS) 1 (1): 9699.

26.Prof. Warudkar A.A, Mr. Valekar N. S.,A Technical and Economical Assessment of Replacement of Coarse Aggregate By Waste Tyre Rubber In Construction, International Journal of Engineering Research and General Science Volume 3, Issue 3, May-June, 2015.

27.Mehmet Gesoglu , Erhan Guneyisi, Ganjeena Khoshnaw, Suleyman Ipek. Abrasion and freezing-thawing resistance of pervious concretes containing waste rubbers,Construction and Building Materials 73 (2014) 19-24.

28.Bhupendra Singh Shekhawat, "Utilisation of Waste Glass Powder in Concrete - A Literature Review" International Journal of Innovative Research in Science, Engineering and Technology 8753, Vol. 3, Issue 7, 2014.

29.Dr. G.Vijayakumar, "Studies on Glass Powder as Partial Replacement of Cement in Concrete Production" International Journal of Engineering and Advanced Technology (IJEAT) ISSN 2250-2459, ISO 9001:2008, Volume 3, Issue 2, 2013.

30.Dhanaraj Mohan Patil, "Experimental investigation of waste glass powder as partial replacement of cement in concrete" International Journal of Advanced Technology in Civil Engineering,Volume-2, Issue-1, 2013.

31.Abhinandan Singh Gill, "Study of Utilisation of Hypo Sludge in High Performance Concrete" International Journal of Engineering Trends and Technology (IJETT), Volume 15 Number 6, 2014.

32.Prof. Jayeshkumar Pitroda, "Innovative use of paper industry waste (hypo sludge) in design mix concrete" International Journal of Engineering and Advanced Technology (IJEAT), Volume-4, Issue-1, 2013.

33.O. Zimbili, "A Review on the Usage of Ceramic Wastes in Concrete Production", International Journal of Civil, Environmental, Structural, Construction and Architectural Engineering, Volume-8, No.-1, 2014.

34.Amitkumar D. Raval, "Ceramic Waste: Effective Replacement of Cement for Establishing Sustainable Concrete", International Journal of Engineering Trends and Technology (IJETT), Volume-4, Issue-6, 2013.

35.Eva Vejmelková, "Application of Waste Ceramics as Active Pozzolana in Concrete Production" IPCSIT, volume - 28, 2012. 
36.Wen-Ten Kuo, "Use of Washed Municipal Solid Waste Incinerator Bottom Ash in Pervious Concrete" Cement \& Concrete Composites 37, 328-335, 2013.

37.Hashmi Mohammed Alhassan, "Characterization of Solid Waste Incinerator Bottom Ash and the Potential for its Use", Journal of Engineering Research and Applications (IJERA), ISSN: 2248-9622, Volume- 2, Issue- 4, 2012.

38.Apurva Kulkarni, "A Miniscule Endeavour for Accomplishing Hypo Sludge Fly Ash Brick in Indian
Context", International Journal of Engineering Trends and Technology (IJETT), Volume- 10, Number -7,2004.

39.Luca Bertolini, "MSWI Ashes as Mineral Additions in Concrete", Cement and Concrete Research 34 (2004) 1899-1906.

40.Kaithwas, Aveen, Murari Prasad, AnkitaKulshreshtha, and Sanjay Verma, "Industrial Wastes Derived Solid Absorbents for $\mathrm{CO}_{2}$ Capture: A Mini Review", Chemical Engineering Research and Design, 2012.

Table 1: Chemical properties of fly ash [40]

\begin{tabular}{|c|c|c|c|}
\hline Component & Bituminous & Sub-bituminous & Lignite \\
\hline $\mathrm{SiO}_{2}$ (in \%) & $20-60$ & $40-60$ & $15-45$ \\
\hline $\mathrm{Al}_{2} \mathrm{O}_{3}$ (in \%) & $5-35$ & $20-30$ & $20-25$ \\
\hline $\mathrm{Fe}_{2} \mathrm{O}_{3}$ (in \%) & $10-40$ & $4-10$ & $4-15$ \\
\hline $\mathrm{CaO}$ (in \%) & $1-12$ & $5-30$ & $15-40$ \\
\hline Loss On Ignition (in \%) & $0-15$ & $0-3$ & $0-5$ \\
\hline
\end{tabular}

Table 2: Comparison of physical \& mechanical properties of Natural Aggregates, BFS \& EAFS [15]

\begin{tabular}{|c|c|c|c|}
\hline Properties & Natural Aggregate & BFS & EAFS \\
\hline SSD Specific Gravity & $2.6-2.8$ & $2-2.5$ & $3-3.7$ \\
\hline Bulk Density(in kg/m ${ }^{3}$ ) & $1600-1900$ & $1120-1360$ & $0.2-2$ \\
\hline Water Absorption (in \%) & $1-4$ & $1-6$ & $20-25$ \\
\hline $\begin{array}{c}\text { Los Angeles Abrasion } \\
\text { Value (in \%) }\end{array}$ & $15-20$ & $35-45$ & $<12$ \\
\hline $\begin{array}{c}\text { Soundness (Sodium } \\
\text { Sulfate) (in \%) }\end{array}$ & $0-5$ & 12 & - \\
\hline $\begin{array}{c}\text { Soundness (Freezing } \\
\text { and Thawing) (in \%) }\end{array}$ & $0-5$ & - & $6-7$ \\
\hline Mohs Scale & $3-7$ & $5-6$ & \\
\hline
\end{tabular}

Table 3: Chemical properties of BFS \& EAFS [15]

\begin{tabular}{|c|c|c|}
\hline Compound & BFS (in \%) & EAFS (in \%) \\
\hline $\mathrm{SiO}_{2}$ & $31-45$ & $10-19$ \\
\hline $\mathrm{Al}_{2} \mathrm{O}_{3}$ & $10-17$ & $1-3$ \\
\hline $\mathrm{Fe}+\mathrm{FeO}+\mathrm{Fe}_{2} \mathrm{O}_{3}$ & $0.1-1$ & $15-30$ \\
\hline $\mathrm{CaO}$ & $34-48$ & $40-52$ \\
\hline $\mathrm{MgO}$ & $1-15$ & $5-10$ \\
\hline $\mathrm{P}_{2} \mathrm{O}_{5}$ & - & $0.5-1$ \\
\hline $\mathrm{MnO}$ & $0.1-1.4$ & $5-8$ \\
\hline $\mathrm{K}_{2} \mathrm{O}$ & $0.6-1$ & - \\
\hline $\mathrm{Na}_{2} \mathrm{O}$ & $0.1-0.5$ & - \\
\hline $\mathrm{TiO}_{2}$ & $2-3$ & - \\
\hline
\end{tabular}

Table 4: Chemical and Physical Characteristics of Silica fume [23]

\begin{tabular}{|c|c|}
\hline Properties & Silica fume \\
\hline $\mathrm{SiO}_{2}$ (in \%) & 90.90 \\
\hline $\mathrm{Al}_{2} \mathrm{O}_{3}$ (in \%) & 1.12 \\
\hline $\mathrm{Fe}_{2} \mathrm{O}_{3}($ in \%) & 1.46 \\
\hline $\mathrm{CaO}$ (in \%) & 0.69 \\
\hline $\mathrm{SO}_{3}$ (in \%) & 0.38 \\
\hline Loss on ignition(in \%) & 3.00 \\
\hline Specific surface (in m $/ \mathrm{g})$ & 18 \\
\hline Particle mean diameter (in $\mu \mathrm{m})$ & 0.36 \\
\hline Density (in kg/m3) & 2260 \\
\hline Insoluble residue (in \%) & 62.85 \\
\hline Glass phase & 96 \\
\hline
\end{tabular}


Table 5: Chemical composition of glass [30]

\begin{tabular}{|c|c|}
\hline Properties & $\begin{array}{c}\text { Waste glass powder } \\
\text { (GLP) }\end{array}$ \\
\hline $\mathrm{SiO}_{2}$ (in \%) & 70.22 \\
\hline $\mathrm{CaO}$ (in \%) & 11.13 \\
\hline $\mathrm{Al}_{2} \mathrm{O}_{3}$ (in \%) & 1.64 \\
\hline $\mathrm{Fe}_{2} \mathrm{O}_{3}$ (in \%) & 0.52 \\
\hline $\mathrm{Na}_{2} \mathrm{O}$ (in \%) & 15.29 \\
\hline Loss on ignition(in \%) & 0.80 \\
\hline
\end{tabular}

Table 6: Chemical composition of hypo sludge [38]

\begin{tabular}{|c|c|}
\hline Chemical Compound & Percentage \\
\hline Silicon Dioxide $\left(\mathrm{SiO}_{2}\right)$ & $5.28 \%$ \\
\hline Calcium Oxide $(\mathrm{CaO})$ & $47.84 \%$ \\
\hline Sulphur Trioxide & $6.41 \%$ \\
\hline Magnesium Oxide $(\mathrm{MgO})$ & $0.19 \%$ \\
\hline Aluminum Oxide $\left(\mathrm{Al}_{2} \mathrm{O}_{3}\right)$ & $0.09 \%$ \\
\hline Ferric Oxide $\left(\mathrm{Fe}_{2} \mathrm{O}_{3}\right)$ & $0.73 \%$ \\
\hline Loss on Ignition & $38.26 \%$ \\
\hline
\end{tabular}

Table 7: Chemical composition of ceramic waste [34]

\begin{tabular}{|c|c|}
\hline $\begin{array}{c}\text { Chemical } \\
\text { Compound }\end{array}$ & Percentage \\
\hline $\mathrm{SiO}_{2}$ & $63.29 \%$ \\
\hline $\mathrm{Al}_{2} \mathrm{O}_{3}$ & $18.29 \%$ \\
\hline $\mathrm{Fe}_{2} \mathrm{O}_{3}$ & $4.32 \%$ \\
\hline $\mathrm{CaO}$ & $4.46 \%$ \\
\hline $\mathrm{MgO}$ & $0.72 \%$ \\
\hline $\mathrm{P}_{2} \mathrm{O}_{5}$ & $0.16 \%$ \\
\hline $\mathrm{K}_{2} \mathrm{O}$ & $2.18 \%$ \\
\hline $\mathrm{Na}_{2} \mathrm{O}$ & $0.75 \%$ \\
\hline $\mathrm{SO}_{3}$ & $0.10 \%$ \\
\hline $\mathrm{Cl}_{2}$ & $0.005 \%$ \\
\hline $\mathrm{TiO}_{2}$ & $0.61 \%$ \\
\hline $\mathrm{SrO}_{2}$ & $0.02 \%$ \\
\hline $\mathrm{Mn}_{2} \mathrm{O}_{3}$ & $0.05 \%$ \\
\hline $\mathrm{L}_{2} \mathrm{O}_{\mathrm{I}}$ & $1.61 \%$ \\
\hline
\end{tabular}

Table 8. Chemical composition of bottom ash [39]

\begin{tabular}{|c|c|c|}
\hline Components & Udine $^{\mathbf{a}}$ MSWIBA & Desio $^{\mathbf{b}}$ MSWIBA \\
\hline $\mathrm{Al}_{2} \mathrm{O}_{3}($ in \%) & 10.29 & 6.36 \\
\hline $\mathrm{Na}_{2} \mathrm{O}($ in \%) & 2.46 & 1.72 \\
\hline $\mathrm{K}_{2} \mathrm{O}($ in \%) & 0.71 & 0.4 \\
\hline $\mathrm{SO}_{3}($ in \%) & 1.21 & 3.43 \\
\hline $\mathrm{CaO}$ (in \%) & 13.25 & 15.89 \\
\hline $\mathrm{Fe}_{2} \mathrm{O}_{3}$ (in \%) & 14.17 & 6.53 \\
\hline $\mathrm{MgO}($ in \%) & 2.02 & 1.99 \\
\hline $\mathrm{MnO}_{2}($ in \%) & 0.06 & 0.16 \\
\hline $\mathrm{P}_{2} \mathrm{O}_{5}$ (in \%) & 1.08 & 0.77 \\
\hline $\mathrm{TiO}_{2}$ (in \%) & 0.38 & 0.85 \\
\hline $\mathrm{SiO}_{2}$ (in \%) & 53.41 & 61.9 \\
\hline
\end{tabular}

a. MSWIBA from an incinerator plant at Udine, North of Italy.

b. MSWIBA from an incinerator plant at Desio in the suburbs of Milan. 


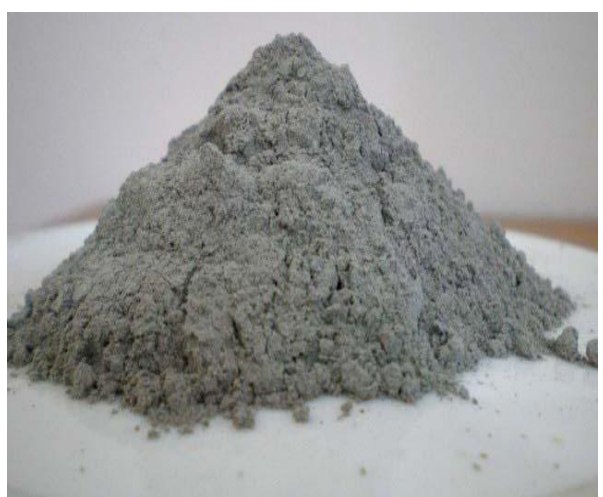

Fig 1(a): Fly ash powder

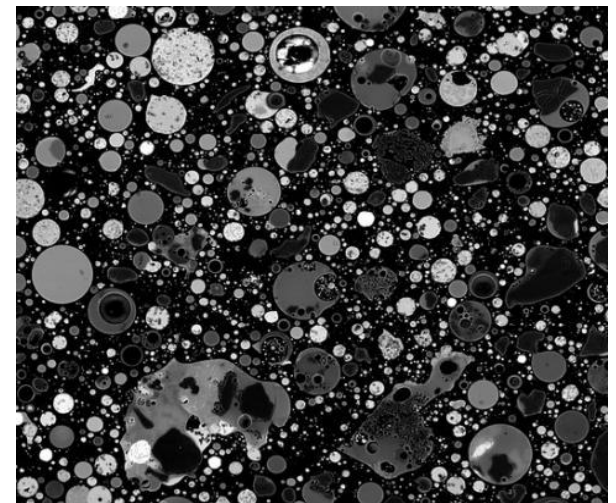

Fig. 1(b): Cross-section of fly ash particles

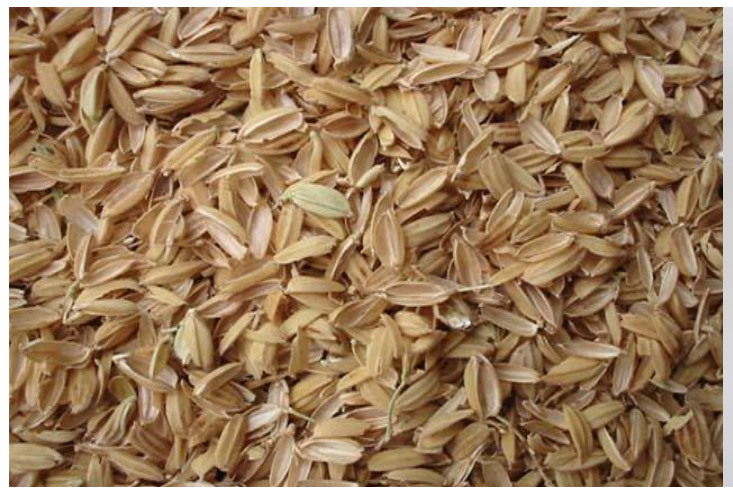

Fig. 2(a) Rice husk

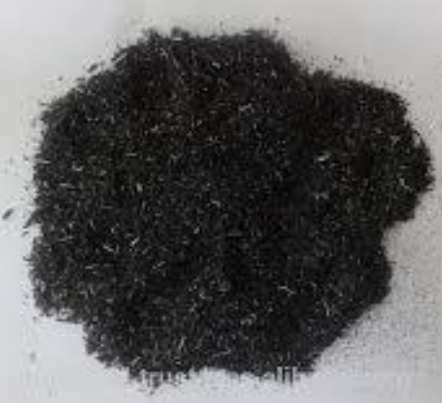

Fig. 2(b) Rice husk ash

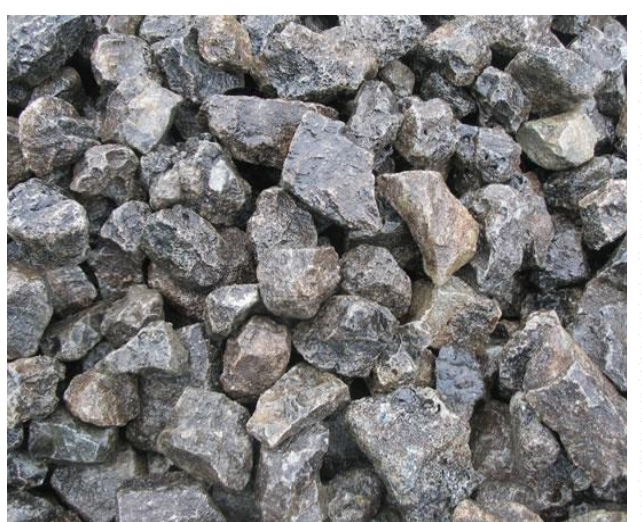

Fig. 3(a): Blast furnace slagFig.

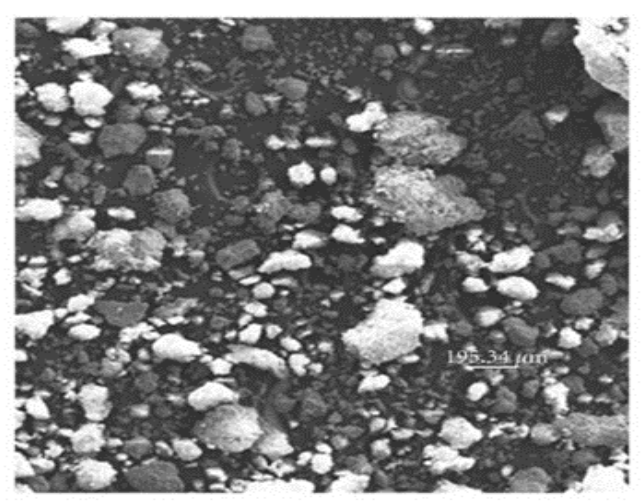

3(b): Sand and silt size particles of EAF slag(Magnification 50X)

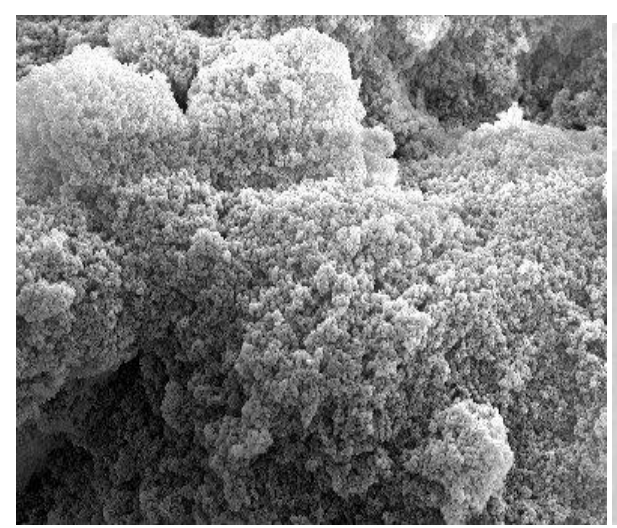

Fig. 4(a)

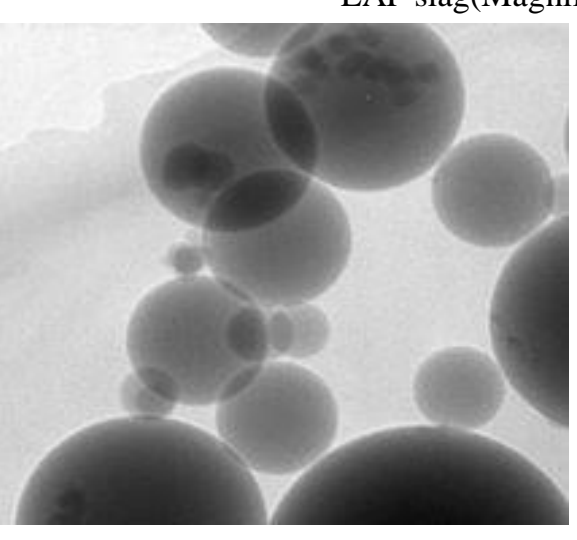

Fig. 4(b)

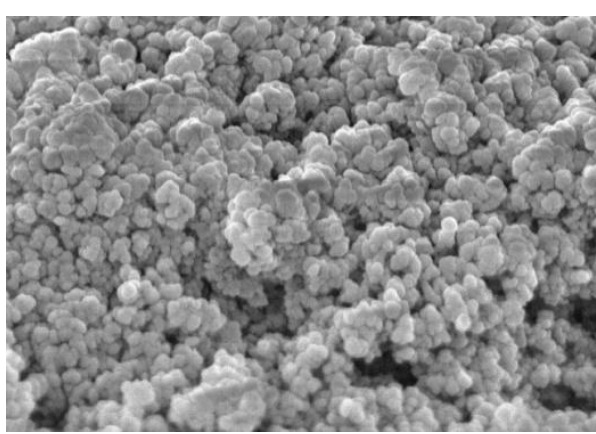

Fig. 4(c)

Fig. 4(a), 4(b) and 4(c): Images of three different sizes of silica fume 


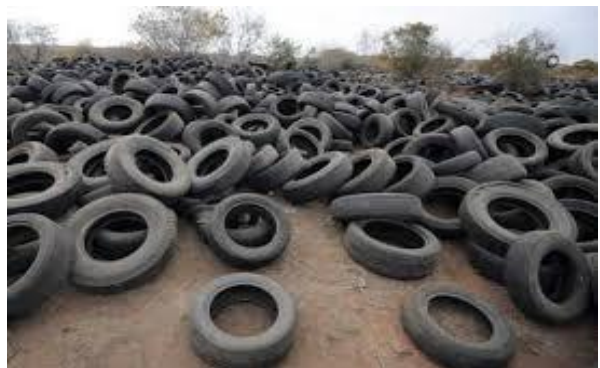

Fig: 5(a): Waste tires

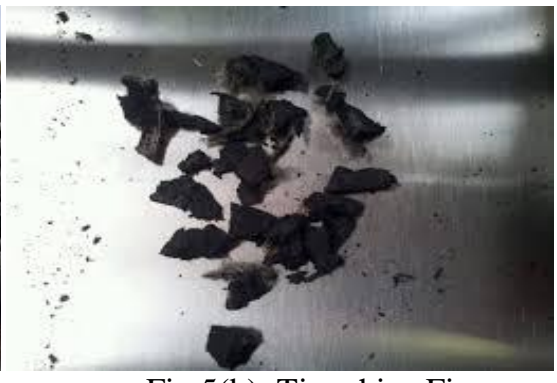

Fig 5(b): Tire chips Fig:

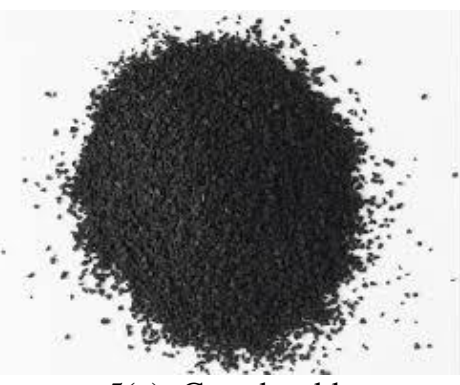

5(c): Crumb rubber

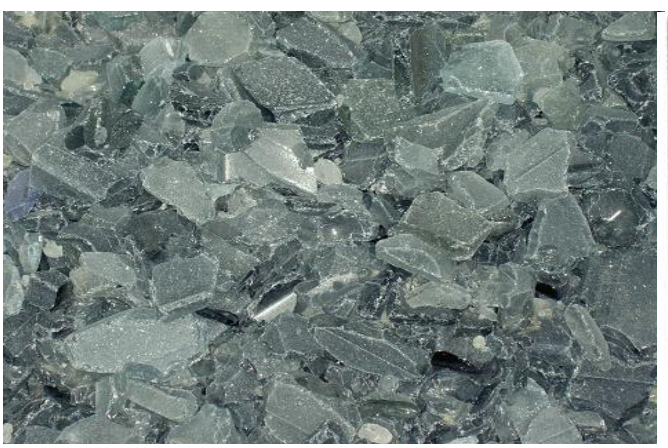

Fig. 6(a)

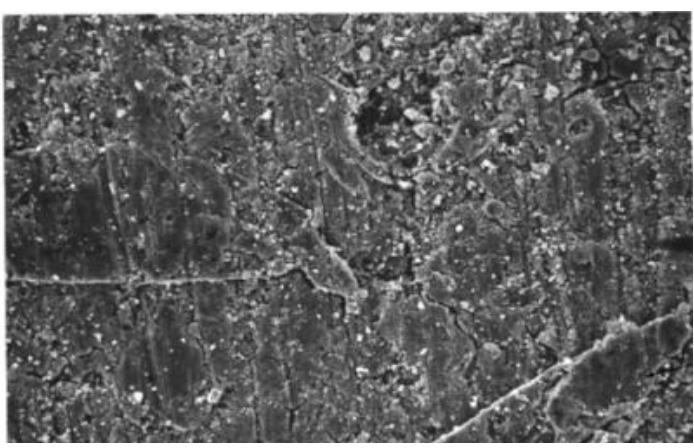

Fig. 6(b)

Fig. 6(a) and 6(b): Images of two different views of glass

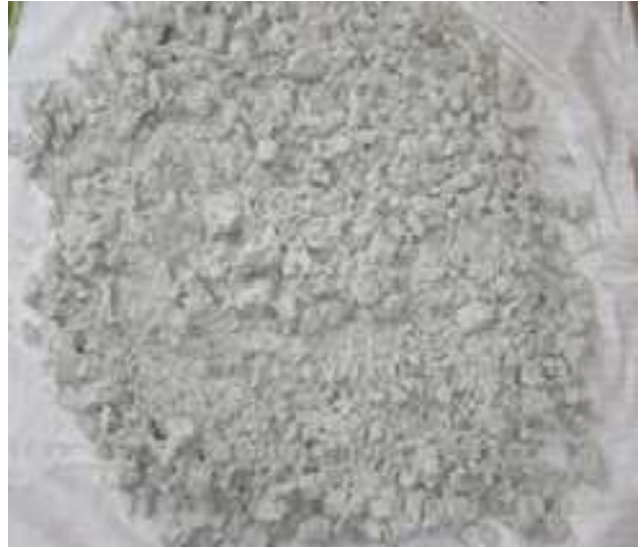

Fig. 7(a)

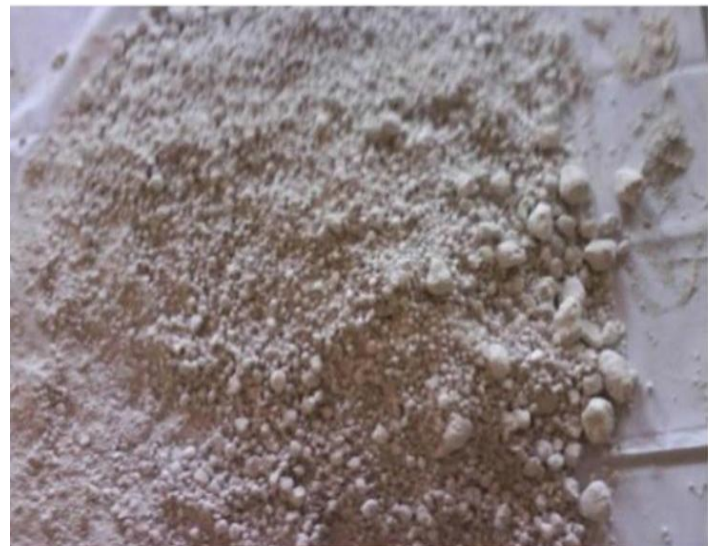

Fig. 7(b)

Fig. 7(a) and 7(b): Images of hypo sludge

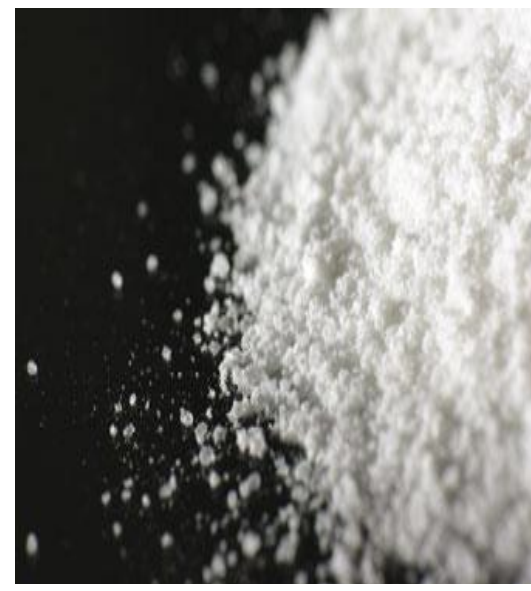

Fig. 8(a)

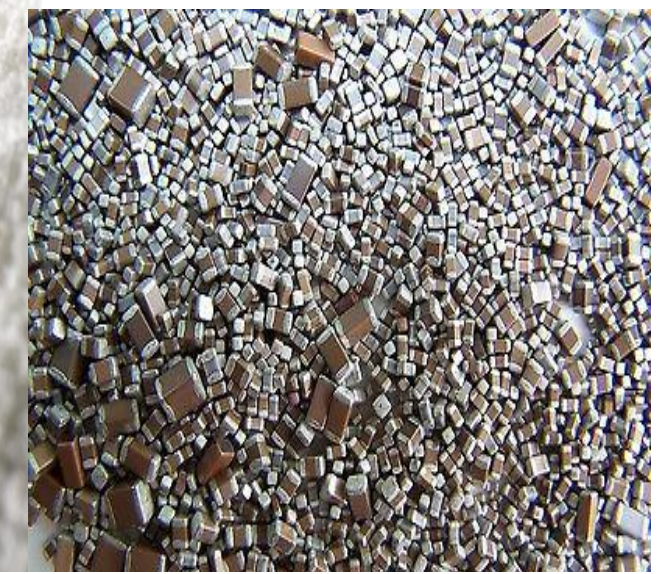

Fig. 8(b)

Fig. 8(a) and 8(b): Images of different views of ceramic powder 


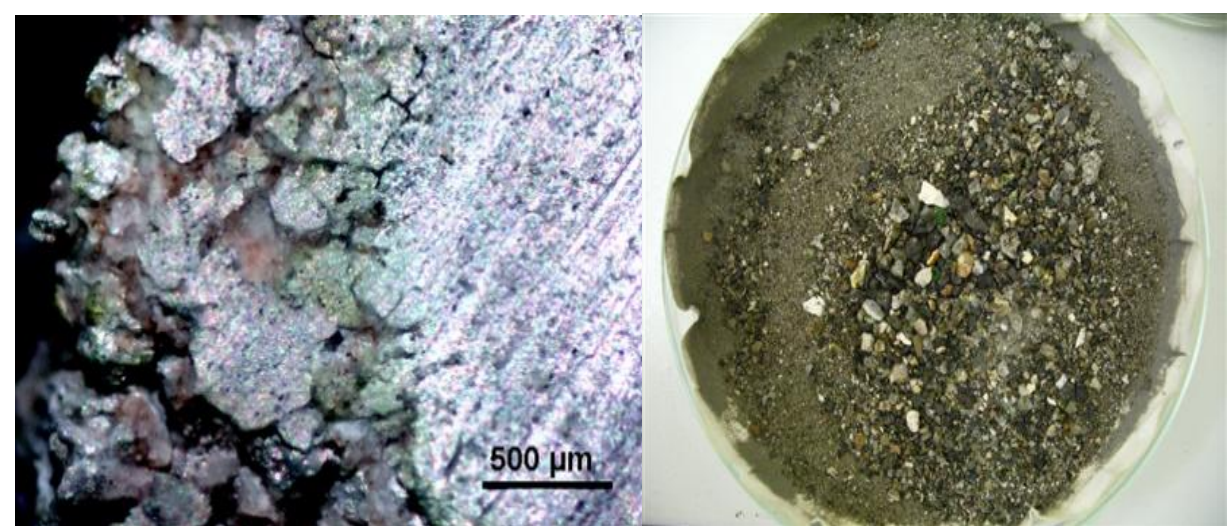

Fig. 9(a)

Fig. 9(b)

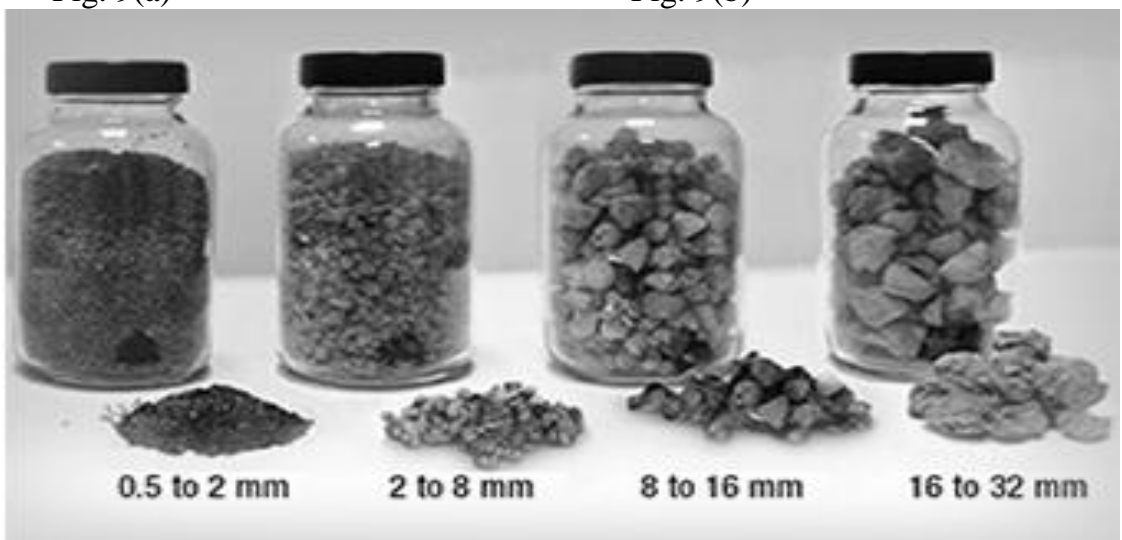

Fig. 9(c)

Fig. 9(a), 9(b) and 9(c): Images of MSWIBA of different sizes. 